\section{SARS-CoV-2: A Professional and social gamechanger - Medical and dental aspects}

Brenda Paula Figueiredo de Almeida Gomes (D), Rodrigo ArrudaVasconcelos (D1, Lidiane Mendes Louzada (D1, Rebecca Figueiredo de Almeida-Gomes (D) 2, Adriana de-Jesus-Soares (D) 1, Lucia Rachel Figueiredo de Almeida (D)3 ${ }^{3}$ Evandro Roberto Baldacci (iD4.

This study reports the SARS-CoV-2 outbreak and its impact on dental practice and education in Brazil. A literature review involving medical and dental interests was performed based on recent general findings about the infection (research and relevant guidelines). COVID-19 is a high transmissible, unpredictable systemic disease, involving a viral replication phase, followed by an inflammatory phase that can evolve into hyperinflammation that leads to a cytokine storm and other serious issues including sepsis, shock and multiple organ failure. The dentists are directly impacted by the new coronavirus as they work with the oral cavity that is irrigated by the saliva and receive the respiratory aerosols and droplets from the patient. In conclusion, the world is facing a completely new situation that deserves the comprehension of the population and close attention of the authorities. Following protocols to attend patients can prevent the dissemination of the virus, cross-infection, and the contamination of health care professionals. New strategies need to be developed to enhance the existing teaching and learning protocols in Universities and to allow research to continue.
${ }^{1}$ Department of Restorative Dentistry, Division of Endodontics, Piracicaba Dental School, State University of Campinas - UNICAMP, Piracicaba, SP, Brazil.

${ }^{2}$ Faculty of Medical Sciences, University Center Lusiada-UNILUS, Santos, SP, Brazil.

${ }^{3}$ Private Practice, Varginha, MG, Brazil

${ }^{4}$ Children's Institute, Hospital das Clinicas, Faculty of Medicine, University of São Paulo, São Paulo, SP, Brazil.
Correspondence: Professor Brenda PFA Gomes Department of Restorative Dentistry, Division of Endodontics. Piracicaba Dental School - State University of Campinas - UNICAMP. Av. Limeira 901. - Bairro Areao. Piracicaba, São Paulo Brazil. 13414-903.

E-mail: bpgomes@fop.unicamp.br

Phone: +55 1921065343 / Fax: +55 192106 5218

Key Words: COVID-19; Dentistry; Infection; SARS-CoV-2.

\title{
Introduction
}

In December 2019, Wuhan, capital of the province of Hubei, China was hit by an outbreak of a severe disease, causing pneumonia and even death (1), known as SARS-CoV-2 or 2019-nCoV. On $7^{\text {th }}$ January 2020, Chinese scientists were able to isolate a new coronavirus from the Wuhan patients, never reported in humans. On $30^{\text {th }}$ January 2020, the World Health Organization (WHO) declared this outbreak as a public health emergency of international concern as 1,760 were affected (2). On $11^{\text {th }}$ February 2020, the new coronavirus, initially named $2019-n \mathrm{CoV}$, was officially renamed as SARS-CoV2, referring to the virus, and COVID-19, referring to the disease, an acronym for "Coronavirus disease 2019" (3).

On $11^{\text {th }}$ March 2020, WHO characterised COVID-19 as a pandemic as 6,315 were affected (2). On $24^{\text {th }}$ March 2021, over 123.9 million cases were confirmed worldwide, with 2,727,837 deaths in 215 countries, being the United States of America (29,592,831 confirmed cases / 538,244 deaths), Brazil $(12,047,526 / 295,425)$, and India $(11,734,058 / 160,441)$ the most affected countries (4).

The SARS-CoV-2 outbreak is especially important due to its high transmission among the population and that $5 \%$ of the infected people will need intensive hospital care, which puts additional pressure on the lack of available infrastructure to treat the serious cases (5). In the context of dental practice, there is an increased risk of cross-infection between dental surgeons and patients.

Therefore, the objective of this work was to report the SARS-CoV-2 outbreak by the medical and dental points of view, and to register the present moment to provide basis for a possible future pandemic.

\section{Infection origin}

New viruses are discovered all the time. Most of them jump from species to species, generally nonhuman, where they go unnoticed to human medicine. However, special attention must be given to any virus that reaches humans for the first time, because it has overcome the first major barrier, as has the new coronavirus. Once inside a human cell it can replicate, allowing its genome to accumulate mutations that could affect its ability to spread easier and even become more virulent. Observing past epidemics, 
this new coronavirus must have come from a non-human animal through another non-human animal (6-8).

SARS passed to humans from a wild animal known as a civet (or raccoon-related cat), which was considered a delicacy in the Guangdong region of China. The cases of the new coronavirus have been linked to the public seafood market in Wuhan, China, the so called "wet markets". Although some aquatic mammals may carry the coronavirus, such as the beluga whale, other classes of live wild animals that are also commercialized in the market (e.g. chickens, bats, rabbits and exotic animals), have been indicated as the most likely sources. With regard to SARS-CoV-2, it is believed that it originated from bats, infected an intermediate mammal host (possibly a pangolin) and then humans. China generally experiences more of these cases because of the size of its territory, its population density, and the close contact that some people have with a wide range of potentially infected animals ( 9 ).

It is widely accepted that many viruses have existed in their natural reservoirs for an exceedingly long time. The occasional and more frequent spill over of these viruses from natural hosts into humans is largely due to human activities, including modern agricultural practices, urbanization, and the com mercialisation of exotic wild species. Therefore, the most effective way to prevent viral zoonosis is to maintain barriers between the natural reservoirs and human society, considering the 'one health' concept $(10)$.

Concern was raised about the seriousness of SARS-CoV-2 and its potential for becoming endemic. The $2009 \mathrm{H} 1 \mathrm{~N} 1$ pandemic influenza virus caused many mild cases, quickly spreading around the globe, and eventually became endemic. Presently, there are four endemic coronavirus strains circulating in human populations (229E, HKU1, NL63, and OC43) (11). If the novel coronavirus follows the pattern seen in the $2009 \mathrm{H} 1 \mathrm{~N} 1$ pandemic influenza, it will spread globally and become a fifth endemic coronavirus within the human population (12).

\section{Viral pathogenicity / transmissibility and immunity}

An RNA virus population does not consist of a single genotype; rather, it is an ensemble of related sequences, termed quasispecies, which arise from rapid genomic evolution powered by the high mutation rate during the replication of the viral RNA genome (13). The diversity of the quasispecies is strongly related with adaptive evolution and the capability to cause illness (14). Coronaviruses possess an error prone RNA-dependent RNA polymerase (RdRP) that produces mutations and recombination events commonly occur within infected cells (14). Coronavirus particles (virions) are spheres with an average diameter of $125 \mathrm{~nm}$, ranging $60-140 \mathrm{~nm}$ (15).

Researchers are investigating what biological mechanisms the virus uses to infect human cells so easily. Some studies focus on the spike glycoproteins on the surface of the virus that interact with a host cell, which facilitates the transfer of viral genetic material into a host cell by adhesion. The viral genetic material is then replicated by the host cell $(9,16)$.

Other researchers are studying the "gateway" or receptor that the virus uses to enter human cells. Studies have pointed out that Sars-CoV-2, similar to SARS-Cov, takes advantage of a specific receptor called ACE2 (angiotensin-2 converting enzyme). ACE2 is on the surface of the cell, and the virus recognizes and binds enabling it to enter the host cell. ACE2 is a protein receptor abundantly present in human tissues such as the epithelia of the lung, the vascular endothelium, the gastrointestinal system, the central nervous system, the olfactory bulb, skin, as well as many other tissues, justifying the entrance of the virus particles into these tissues $(17,18)$. The diversity of the attack on different systems of the organism explains the complexity and clinical presentation of this disease.

After binding to the cellular receptor, a rapid replication in ACE-2 gene is crucial for the virus to enter human cells (18). Once inside, the virus makes copies of itself, evades the cell with thousands of copies and it is ready to start infecting other cells (18).

Therefore, Sars-CoV-2 tends to have a crucial characteristic: it is found both in the upper respiratory tract, spreading easily to the lower tract and producing a serious disease in the lungs that can be fatal. When the virus attacks the epithelia of the lung, the most common symptoms of COVID19 arise difficulty breathing and coughing, which occurs when the lungs try to get rid of the infection $(17,18)$.

The mortality rate due to COVID-19 is higher among people who suffer from chronic health problems (comorbidities), such as hypertension, diabetes, or chronic obstructive pulmonary disease. Probably, changes in metabolism caused by these diseases can trigger a series of biochemical events that lead to an increase in the expression of the ACE-2 gene, the protein which the virus uses to infect lung cells. An alternative explanation is that as SARS-CoV-2 is able to infect a broad range of tissues and that 
any of these tissues that is compromised by a pre-existing condition is hit harder than healthy ones leading to complications during COVID-19. The increase in the expression of ACE-2 and other genes that facilitate infection, including TMPRSS2 and Furin, causes these patients to have a greater number of cells affected by the virus and, consequently, a more severe form of disease. These findings suggest these chronic diseases change, it is not yet known how, the body's epigenetic program, making these enzymes more active and, consequently, increasing the expression of ACE-2 and favouring the infection of lung cells by SARS- CoV-2 (18). Senior people are also particularly at risk due to their reduced immune response and their diminished capacity to heal the injured epithelium (19). The elderly population have reduced mucociliary clearance, allowing the SARS-CoV-2 to propagate to the gas exchange units of the lung promptly (19).

It should be mentioned that although children can become infected with SARS-COV-2, they generally do not develop severe symptoms, probably due to their stronger innate immune response; higher proportion of total lymphocytes and lower proinflammatory cytokine response; lower prevalence of co-morbidities; higher mucosal colonization by viruses and bacteria; less ACE2 receptors with lower affinity, among other factors (20).

An important aspect of the virus-related transmissibility is the reproduction number, known as the Ro number. In epidemiology, R0 is defined as the average number of individuals who will contract the infection after contact with an infected person. The capacity of a virus to propagate is often considered an important factor in the severity of a disease (14). Pathogenicity is defined as the absolute ability of an infectious agent to cause disease/damage in a host-an infectious agent is either pathogenic or not (21). In the case of SARS-CoV-2, it has been suggested that, occasionally, an infected person with highly severe COVID-19 will be able to pass the infection to a few individuals, while those with a moderate illness or latent infection have the potential to spread the infection to many more individuals, nevertheless it is not completely understood its molecular mechanism. A potential result is that mutations in the virus that cause a low health risk to the individual may cause elevated threat to the population (14).

The estimation of the WHO is that the RO is between $1.4-2.5$. Other investigations estimate between $2-3$. Some "superspreaders" have been found to contaminate up to 16 persons. For epidemic control, R0 needs to be below 1 (14).

As a reference, measles has a famously high $\mathrm{R} 0$ of approximately 12 to 18 , whereas influenza has an R0 of 2. However, within the confined spaces of buildings with closed environments, the R0 of SARS-CoV-2 has been estimated to be significantly higher (ranging from 5 to 14) (9).

The adoption of social distancing aims to reduce the speed of transmission of the virus, flattening the transmission curve. It is not expected to prevent all transmission. However, with the social distancing, the local health system should have time to reinforce the structure with equipment, respirators, personal protective equipment, beanies, masks, safety glasses (goggles), gloves, aprons, laboratory tests, human resources trained, clinical doctors and intensivists, nurses, physical therapists, biochemicals, biomedicals, epidemiologists, among other professionals and not be subjected to a tsunami of patients requiring intensive hospital care. The concern with the rapid spread of the virus and the lack of structure in hospitals for the treatment of serious cases, lack of beds in ICUs, has prompted various state leaders from the various affected countries, to take measures such as extreme forms of social isolation (lockdown), including the closing of local commerce and borders and even state decrees of public calamity. There are studies showing contagion capacity (R0) in Wuhan before social isolation was 3.8 and after almost a month of isolation, this figure dropped to 0.7 (12).

There is "no herd immunity" effect yet since the virus is novel in humans, no pre-existing immunity. Social distancing (quarantine, work from home, school closures) is only a "brake" to slow spread (22).

There is still little concrete evidence about the duration of immunity to COVID-19. It is believed that patients who have successfully beaten the virus have probably created immunity to it, although there is insufficient data available. There are reports of patients being infected more than once, but this is believed to be due to incorrect testing. However recent experiments with rhesus macaques would indicate that some degree of resistance to a second infection is probable in humans (23).

While the issue of immunity is one of the most important at the moment, especially how efficient future vaccines against the new coronavirus will be, we still have to understand the transmissibility of the virus and what type of social isolation is necessary with the existence of a population with a degree of immunity due to the individuals that will recover during the wave of infection with SARS-CoV-2. 


\section{Transmission pathways}

One of the main differences between Sars-CoV-2 and the other two coronaviruses, which caused SARS and MERS, is that the latter two adhered to many more cell receptors and therefore reproduced faster (10). This made the symptoms of SARS and MERS appear much faster and, therefore, patients could isolate themselves or be isolated before passing the virus to other uninfected individuals.

With SARS-CoV-2, which seems more adapted to spread, the symptoms do not appear immediately or may not even appear, but the virus can still be transmitted. A person can begin to infect others before their symptoms appear and for up to seven days during the infection. Herein lies the real danger of SarsCoV-2, which is why authorities around the world place so much emphasis on measures of social distancing. The virus can only survive if it finds a new host to infect. When a person self-isolates for 14 days, the possibility of transmitting the virus to others is eliminated or at least is drastically reduced (24).

The most common route of infection to spread the SARS-CoV-2 is by direct human-to-human transmission as previously noted in SARS-CoV and MERS-CoV, such as transmission by contact, droplets, aerosols and fomites containing or covered with viral particles, the most well-known routes of transmission (25). In addition, growing evidence points to a potential route of infection by fecal-oral transmission (26), but this is still conjecture (27).

After touching contaminated surfaces, the virus can be transmitted by touching the nose, mouth, or eyes. SARS-CoV-2 can remain viable depending on the surface, ranging from a few hours on copper up to 1 - 2 days on steel or plastic surfaces. However, this route of transmission does not appear to be the most efficient (28).

Transmission of SARS-CoV-2 through the air is another possible route of transmission as studies have detected positive air samples for SARS-CoV-2 $(6,28)$. On the other hand, negative air samples have also been reported $(6,29)$. In a study from Iran, authors reported that all air samples collected $5 \mathrm{~m}$ around the patients were negative (30). Recent experiments with aerosols and droplet released during talking and breathing have indicated the most probable route of transmission especially in an enclosed environment such as hospitals, where the distance between individuals is small, schools and churches (31).

Although there is not enough evidence whether the samples collected are viable or not, or if the viral load is sufficient to allow infection and cause COVID-19, however, taking precautions to avoid airborne contamination by aerosols and droplets seems to be logical (31).

All of these points reinforce the necessity for the population to adopt standard basic recommendations to prevent the spread of COVID-19, such as frequent cleaning of hands using alcoholbased hand rub or soap and water; covering the nose and mouth with a flexed elbow or disposable tissue when coughing and sneezing or better using masks; and avoiding close contact with anyone that has a fever and cough, among others (32).

\section{Incubation period}

The estimated period of incubation ranges from 2 - 14 days (2), although the individual will normally develop symptoms between 2 and 7 days in 75\% of the cases (33) and after 14 days in less than $1 \%$ of cases (34). The median incubation period is $4-5$ days $(6,12)$.

Research suggest that the new coronavirus may remain in the mouth and nose (upper respiratory tract) for a week before it reaches the lungs, trachea, and bronchi (lower respiratory tract) (24). Moreover, the virus is also expelled from the body in large quantities, through the faeces, in the first two weeks of the disease, but it is still found in them up to 26 days later, indicating how it acts in the gastrointestinal system (27).

\section{Main symptoms}

During the initial phase, atypical symptoms are common among patients with COVID-19 including fever, dry cough, absence of nasal congestion, persistent headache, anorexia, dizziness, asthenia (lack of energy and strength), chills, myalgia, conjunctivitis, diarrhoea and nausea/vomiting. In the later stages, more distinctive symptoms are present including anosmia (loss of smell), ageusia (loss of taste), dyspnoea, (shortness of breath), chest pain, haemoptysis, vascular lesions (35-38).

As the virus seems to affect the ambiguous core of the brainstem, a common clinical pattern has emerged, with a remarkable discrepancy between relatively well preserved lung compliance and severely compromised pulmonary gas exchange, leading to grave hypoxaemia without the expected proportional signs of respiratory distress (39). Therefore, a patient without tachypnoea or tachycardia does not necessarily mean that the individual is not in a serious condition. 


\section{Phases of the infection / inflammation}

The disease can be classified according to the response phases. There is the viral response phase, when the virus multiplies (0-9 days, peak increases after 4-5 days); and the host inflammatory response phase to this viral attack (7-28 days), where the greatest worry is that the patient can enter a more severe phase during the $8-9^{\text {th }}$ day of this inflammatory phase. Therefore, it is necessary to avoid this phase since the patient can enter this phase quickly and with great intensity, where the disease progresses to the gas exchange units of the Iung and infects alveolar type II cells.

According to Mason (19), there are three phases of the COVID-19 corresponding to different clinical phases of the disease:

Stage 1: Asym ptom atic state (initial 1-2 days of infection)

Stage 2: Upper airway and conducting airway response (initial 3-5 days)

Stage 3: Hypoxia, ground glass in filtrates, and progression to acute respiratory distress syndrome (ARDS) (approximately 6-10 days)

Unfortunately, only about $20 \%$ of the infected patients will progress to stage 3 , where the disease progresses to the gas exchange units of the lung and infects alveolar type II cells. Approximately $20 \%$ of patients develop dyspnoea requiring hospital admission, typically between days 6-10.

The evolution of the infection differs between individuals, from a pulmonary infiltrate to harsh ARDS event. A life-threatening lung disease is developed in a slight percentage of individuals with COVID-19, characterised by severe pneumonitis, which can evolve to acute respiratory distress syndrome (ARDS), including direct and indirect injury to alveoli; deep hypoxemia with well-preserved lung compliance seems common early. A "cytokine storm", an important reaction similar to haemophagocytic lymphohistiocytosis $(\mathrm{HLH})$, affects some of the critical patients (40); myocarditis/cardiomyopathy (rare event) (41); spread intravascular clotting (42-44), and thrombotic complications may occur. It is very important to monitor the levels of fibrin-related markers [D-dimer and fibrin degradation p roduct (FDP)], which can be moderately or markedly elevated in all deaths by COVID-19, suggesting that common coagulation activation and a secondary hyperfibrinolysis condition is a complication of SARSCOV-2 infection in these patients (42-44).

In most cases of ARDS, patients will have to be supported by supplemental oxygen and mechanical ventilation soon after the start of the stage 3 symptoms. Individuals must be monitored carefully and the adequate medication until specific antiviral drugs or new medication regimes to treat the consequences of SARS-CoV-2 infection become available (19).

Mortality percentage of acute respiratory distress syndrome ranges from 30 to $40 \%$ (45). Lung function progressively improves over a period of 6 to 12 months; however, significant damage and a lower-than-normal lung volume are expected in those recovering from the disease (45). The diminished quality of life resulted as a consequence of low lung function can lead the patient to develop anxiety, depression, and post-traumatic stress disorder.

\section{Spectrum of severity}

After infection due to SARS-CoV-2, illness can range from no symptoms to severe COVID-19. A proportion of infected individuals can continue with no symptoms although the precise proportion is not known. The percentage of each degree of severity experienced in a cohort study: mild or moderate $(81 \%)$, severe $(14 \%)$ (dyspnoea, $R R \geq 30,0_{2}$ saturation $\leq 93 \%$, PF ratio $<300$, and/or lung infiltrates); critical (5\%) (respiratory failure, septic shock and/or multiple organ dysfunction) (46).

\section{Testing and assays}

The recommended diagnostic test is the RT-PCR (47). In the presence of extensive community transmission of the virus and/or limited laboratory resources, it can be recommended to perform RTPCR in a single discriminatory target (47). In cases of specimens with non-interpretable results, confirmatory testing is recommended. In this cases, re-sampling or repeating tests in a previous collected sample can be performed. A combination of oropharyngeal and nasopharyngeal swabbing into a single diagnostic test can be performed in a situation of lack of testing materials.

Several commercial detection and serological assays for SARS-CoV-2 are on the market, however, information on their clinical performance is still limited. Validation of commercial assays is an urgent priority (47). Table 1 shows the complementary use of RT-PCR and serological tests to define the clinical stage of the infection in patients with COVID-19. The RT-PCR test will determine the 
presence of SARS-COV-2 during any phase of the disease while the virus is replicating, whether symptomatic or asymptomatic, this normally occurs up to the period between $8^{\text {th }}-10^{\text {th }}$ day. Individual assays for the presence of $\lg M$ or $\lg G$ against SARS-COV-2 can help to define whether the infection is active, after the $14^{\text {th }}$ day, or if the individual is in the convalescent phase. IgM being the initial response to infection, followed by the presence of $\lg M$ and $\lg G$ during the symptomatic phase and finally only $\lg \mathrm{G}$ during the final and recovery phases.

Table 1. Clinical significance of the RT-PCR and serological assays ( $\lg M$ and $\lg G$ ) during the phases of infection

\begin{tabular}{|c|c|c|c|c|}
\hline \multicolumn{3}{|c|}{ Results } & \multirow{2}{*}{ Clinical significance $^{*}$} & \multirow{2}{*}{ Reaction time ${ }^{* *}$} \\
\hline RT-PCR & $\lg M$ & $\lg G$ & & \\
\hline Negative & Negative & Negative & Negative (Incubation period) & From day 0 to 2 \\
\hline Positive & Negative & Negative & Infection (viral phase) & Up to the $5^{\text {th }}$ day \\
\hline $\begin{array}{c}\text { False- } \\
\text { negative }\end{array}$ & Positive & Negative & In case of false-negative RT-PCR. Repeat RT-PCR & Nearly $7^{\text {th }}$ day \\
\hline Positive & Positive & Negative & Inflammatory phase of infection & From the $7^{\text {th }}$ day \\
\hline Positive & Positive & Positive & Inflammatory phase of infection & Nearly $14^{\text {th }}$ day \\
\hline Positive & Negative & Positive & Inflammatory phase of infection & Nearly $21^{\text {st }}$ day \\
\hline Negative & Negative & Positive & Infection in evolution. Perform RT-PCR for confirmation & Nearly $28^{\text {th }}$ day \\
\hline Negative & Negative & Positive & Previous contact with the virus & After $28^{\text {th }}$ day \\
\hline
\end{tabular}

The use of saliva for COVID-19 detection represents a potential for clinical diagnosis as it contains live SARS-CoV-2 (49). This virus encountered in saliva may come from the nasopharynx, lower respiratory tract and infected salivary glands, the latter occurring in the early part of the disease process (49).

\section{Chest computed tomography}

Chest computed tomography (CT) is of great significance for diagnosing and managing patients with COVID-19 (50). Nevertheless, the diagnosis of early ground glass opacity (GGO) with plain chest radiography is easily missed (50). High-resolution CT (HRCT) is a valuable tool for initial diagnosis of COVID-19 (51). HRCT permits the evaluation of the lung lesions, enabling doctors to well comprehend the pathological process. With successive $\mathrm{CT}$ examinations, the incidence, progression, and prognosis of COVID-19 can be understood (50).

\section{Treatment}

Currently there is no specific treatment for COVID-19 (48). In cases of patients requiring supportive care and/or oxygen supplementation, it can be performed via non-invasive or mechanical ventilation. Patients in severe condition may require vasopressor support and antibiotic therapy as secondary microbial infection may occur. Cardiomyopathy, pulmonary embolism, and sudden onset death have been reported. The World Health Organization's COVID-19 Clinical Network to continue collecting data to assess the frequency of COVID-19-related complications.

A number of pharmaceuticals are being used for severe and critically ill patients as potential treatments against SARS-CoV-2, including ribavirin; interferon $\beta-1 \mathrm{a}$; the antiviral combination lopinavir/ritonavir; the combination of a FDA-approved broad spectrum anti-parasitic agent ivermectin, which has been shown to have in vitro anti-viral activity against a broad range of viruses (52), with azithromycin in the asymptomatic phase, the antimalarial chloroquine/hydroxychloroquine, or the antiviral nucleotide analogue Remdesivir and the antiviral Favipiravir in the symptomatic phase (53). Several clinical trials are recruiting patients globally to assess the effect of different treatment options 
(48), not only in critically ill patients, but also in the early phases of the disease, in order to establish protocols to control the progression and onset of the more life-threatening symptoms (54).

A study undertaken in China involving 199 patients showed no favourable effect in using lopinavir/ritonavir on the clinical course or the mortality compared to control (standard treatment) (55). Remdesivir showed to be more effective than placebo in reducing the recovery time in adult patients and decreased infection on respiratory tract; however, there was no significant effect on mortality rate (56).

In vitro studies have shown hydroxychloroquine to modify the uptake of the coronavirus in cells. Furthermore, clinical studies and minor case series have used hydroxychloroquine (57). However, at this moment, the use of hydroxychloroquine remains undefined. The use of azithromycin has also been investigated as this macrolide shows immunomodulatory effects via macrophage activation and inhibition of neutrophilic inflammation (58).

Systemic use of steroids has not been recommended because they might increase the viral replication and shedding of the virus along with other steroid- related side effects (59). However, recent research has shown that the use of dexamethasone may be helpful for patients hospitalized with COVID19 who require oxygen, including those on ventilators (60).

Blocking of the inflammatory cascade through IL-6 and IL-4 blockers have also been investigated. Currently, there is no evidence that reports that NSAIDs (non-steroidal anti-inflammatory drugs) aggravate COVID-19 clinical condition via augmented expression of ACE2 (angiotensinconverting enzyme 2), whose receptor have been associated with virus entrance in the target cells (48).

The use of anticoagulants (low molecular weight heparin, IMWH) in COVID-19 positive patients have been also investigated, particularly in patients with a risk of venous thromboembolism (VTE), in which the D-dimer levels are high $(42,61)$. Hospitalized patients should be categorized for risk of VTE to be given the best prophylaxis for each specific case. With regard to continuing prophylaxis (especially chemical prophylaxis) after patient discharge, there is no evidence on which to base systematic prescription; It is suggested that patients are once again categorized at discharge for thrombotic and haemorrhagic risk and that the best treatment should be chosen on this basis, in addition to instructing all discharged patients to remain active when confined at home (61).

\section{Vaccine}

Over 200 vaccine candidates are in development worldwide. Sixty of them in clinical development, also called drug development process that includes drug discovery, pre-clinical research and clinical trials (62). The World Health Organization launched in 2020 the COVAX Facility, co-led by the Coalition for Epidemic Preparedness Innovations (CEPI); Gavi and the World Health Organization (WHO), alongside key delivery partner UNICEF. $(62,63)$. COVAX is the vaccines pillar of the Access to COVID-19 Tools (ACT) Accelerator (63). The ACT Accelerator is a ground-breaking global collaboration to accelerate the development, production, and equitable access to COVID-19 tests, treatments, and vaccines (63).

Currently, 7 different vaccines are under application in several countries. Overall, vulnerable individuals are top priority for vaccination. A total of $422,798,534$ vaccine doses were administrated in the world (24 ${ }^{\text {th }}$ March 2021) (62).

\section{Main impacts in dental practice in brazil}

The dentists are directly impacted by the new coronavirus as they work with the oral cavity that is irrigated by the saliva and receive the respiratory aerosols and droplets from the patient. The fact that SARS-CoV-2 remains and replicates in the upper respiratory tract (mouth and nose) for approximately a week before reaching the lungs, trachea and bronchi, and before the classical symptoms of the disease are apparent, makes the disease even worse for dentists, who have close contact with the patient during treatment. SARS-CoV-2 in saliva may come from the nasopharynx, lower respiratory tract, and infected salivary glands (which occurs early in the disease process). The situation is made worse because certain dental procedures use high-speed handpieces or ultrasonic instruments, which will convert any secretions, saliva, or blood into aerosols that are released into the surroundings. Dentists normally follow procedures where the dental apparatus could be contaminated with various pathogenic microorganisms during use or when exposed to a contaminated clinic environment. Thereafter, infections can occur through the puncture of sharp instruments or direct contact between mucous membranes and contaminated hands (64). 
Now the dentists must deal with a different concept, the patient may be the source of the contamination that could infect the dentist and the clinical environment. Due to the unique characteristics of dental procedures where a large number of droplets and aerosols could be generated, the standard protective measures in daily clinical work are not effective enough to prevent the spread of COVID-19, especially when patients are in the incubation period and are unaware that they are infected, or they choose to conceal the fact that they are infected (48).

The Brazilian Dental Federal Council (63), based on the American Dental Association guidelines (66), has recommended that dental practitioners attend only dental emergencies and urgent care, with elective treatment not being recommended at the moment.

According to the Brazilian Dental Federal Council, from a total of 40,000 interviewed professionals, $82 \%$ kept their activities during the pandemic, most of them following recommended biosafety measures (67).

\section{Biosafety in dental care}

During this hazardous time, it is important to keep in mind certain important points before attending a patient. CDC $(32), \operatorname{ADA}(66)$ and other authors $(68,69)$ recommend:

a) Maintain the ventilation and air conditioning system working properly

b) Patient placement

c) Number of patients to be attended and protective measures

d) Administrative controls and work practices

e) Use of personal protective equipment (PPE)

\section{Dental procedures}

Before each dental procedure, it is recommended that the patient performs a mouth rinse with dental mouthwash components that can include antimicrobial products such as ethanol, chlorhexidine $(0.2 \%)$, cetylpyridinium chloride $(250-750 \mu \mathrm{g} / \mathrm{ml})$, hydrogen peroxide $(1.5 \%)$ and povidone-iodine $(1 \%)$ (70).

With regard to the inanimate clinical environment, disinfection of the surfaces using $62-71 \%$ ethanol, $0.5 \%$ hydrogen peroxide, and $0.1 \%(1 \mathrm{~g} / \mathrm{L})$ sodium hypochlorite $(71)$ is critical to prevent crossinfection. Consider extending the time between appointments so there is enough time to clean all the surfaces.

Performing an appropriate isolation of the tooth with rubber dam and gingival barrier before starting to access the cavity to prevent saliva infiltration. Subsequently, a disinfection protocol with $30 \%$ $\mathrm{H}_{2} \mathrm{O}_{2}(\mathrm{v} / \mathrm{v})$ for 30 seconds, $2.5 \% \mathrm{NaOCl}(30$ seconds) and then neutralisation with $5 \%$ sodium thiosulfate (72-74) to eliminate microorganisms in the operatory field. Next, it is recommended that the water supply from the equipment is disconnected and cooling is performed manually using sterile saline and syringe (72-74).

A four-hand treatment is desirable, as the main operator can focus on the dental treatment and maintain the aseptic chain, while the auxiliary personnel can focus on biosafety by aspirating the saliva. Moreover, high-efficiency surgical suctions should be preferred.

Consider extending the time between appointments so there is enough time to clean all the surfaces. Avoid greeting patients with kisses and handshakes before/after appointments.

All professionals and their staff should wear respirator mask N 95/PFF2 or equivalent.

Reinforce the use of aprons, protective clothing (grammage of $50 \mathrm{~g} / \mathrm{m}^{2}$ weight), caps, gloves, eye protection, face shield.

Reinforce the use of masks for the patients before and after their attendance. Protect them with caps, aprons.

Wash hands carefully before and after attending every patient.

After every appointment, immediately clean and disinfect all the surfaces and the working environment.

Follow strictly the universal procedures for autoclaving and disinfecting.

The use of peracetic acid for immersion of the dental instruments before autoclaving reduces the microbial load.

The use of cone beam computed tomography (CBCT) should be considered as it prevents from the cough and gag reflex that may occur during intraoral radiography (71). In the absence of this imaging tool and necessity of taking intraoral radiography, sensors should be double-covered to prevent perforation and cross-contamination (71). 


\section{Main impacts in teaching and learning}

Due to the increasing number of COVID-19 in the Brazilian territory over the last months, Universities have stopped their activities involving presential teaching, research, and patient care for an undefined period.

With regard to Undergraduate teaching, most of the Universities have completely ceased their face-to-face activities. However, digital platforms ensure distance learning. As for Postgraduate courses remote activities are being held. In most of the cases, ongoing research is based on surveys and data processing.

In order to provide a safe environment in Dental Schools, The Brazilian Association of Dental Education (ABENO) has developed a guideline on the following topics: Clinical settings, flow of patients, daily routine, biosafety protocols, and training. Overall, it suggests strategies to reduce aerosol, rigorous process of disinfection and sterilization, and how to behave before, during and after being into the dental school $(75,76)$.

It is important to point out that Brazil is a continental dimensions country with huge issues regarding social inequality. Although the use of internet seems to be an important tool for distancing learning, in some regions of the country, not all students have access to a network, which creates problems when trying to maintain the students' level of learning. In north Brazil it is a characteristic to have the main public universities in the capital of each state, therefore, students from neighbouring cities, most of them with low infrastructure, including riverside communities, have to move to gain access to a University education.

The Federal Government, through its main funding agencies: CAPES (Brazilian Coordination for the Improvement of Higher Education and Graduate Training Personnel) and CNPq (National Council for Scientific and Technological Development), has launched programs to combat epidemics/pandemics. CAPES will allocate $R \$ 200$ million (approximately US\$23,42 million) over the next four years to projects that deal directly or indirectly with studies involving COVID-19. Scholarships will also be awarded in addition to the amount already projected for the scholarship grant model, and funding and capital resources of up to $\mathrm{R} \$ 345,000$ per project, for up to 30 selected research projects. CNPq has released over a total of $R \$ 50$ million (approximately US $\$ 8.5$ million) to support 11 research projects involving COVID-19. São Paulo Research Foundation (FAPESP) selected projects in the so-called Rapid Implementation Supplements against COVID-19. FAPESP researchers have redirected resources from their grants to the themes associated with COVID-19 and the agency has approved resources and PostDoctoral Scholarships in the Regular Aid Supplement for Rapid Implementation (APR-SRI). The call is aimed at research proposals of up to 24 months as supplements to current projects in the forms of Research Aid - Thematic Project, Young Researchers, Research, Innovation and Dissemination Centers or Research Centers in Engineering. Nonetheless, all over Brazil, State Research Agencies are playing a relevant role as inducers for Science, Technology, and Innovation, issuing specific calls for proposals as a part of the state fight against the coronavirus.

\section{Final remarks}

COVID-19 is a complex, unpredictable and systemic disease, involving a viral phase, followed by an inflammatory phase that can evolve to an hyperinflammation, that leads to a cytokine storm and other very serious problems, such as sepsis, shock, multiple organ failure. In this phase, there is the need for intensive care in hospitals.

Early in 2020 WHO estimated it would take at least 18 months to develop a vaccine against SARSCIV-2, however, it was achieved in less than 12 months. In contrast, the speed of producing and acquiring the vaccines as well as the distribution to the general population varies from country to country, and even from state to state. This means that countries may have to alternate periods of isolation and relaxation during this period depending on epidemiological monitoring. Besides the effects of these long periods of isolation, the fear of being infected will be present in the population for a long time, giving rise to behavioural consequences such as depression and panic syndrome.

The key to the return of normal socio-economic activities with the preservation of life, relies on the development of a treatment for this disease, making it at least controllable (54). Therefore, in the meantime, the adoption of standard basic recommendations by all the members of the population to prevent the spread of COVID-19, such as the use of masks, social distancing, and quarantine to flatten the transmission curve, must occur to allow the hospital services to cope. However, adopting these measures will retain a large number of people that have not been exposed to the virus, which susceptible 
to successive waves of infection. Only when a large part (60-70\%) of the population has already become infected with the virus, may herd immunity be able to function and limit the spread of the virus. This could also happen when a mass vaccination occurs. However, reaching a herd-immunity threshold depends on factors such as vaccine hesitancy, the emergence of new variants, the delayed arrival of vaccinations for children, among others.

The pandemic has shown that there is a need for rigorous and serious public policies to organize not only health, but also the economy. A good relationship should exist between Science, Public Health and Politics. The transformations needed are countless and include changes in politics, economics, health services, business models, social relations, culture, social psychology and the relationship between the city and public space, among other things.

The world that we used to live in before coronavirus no longer exists. Global changes that would normally take decades had to implemented in a matter of months. It is possible to say that the SARSCOV-2 pandemic marked the end of $20^{\text {th }}$ century, a century that was considered highly technological, but its limitations have been exposed by this coronavirus.

The WHO continues to emphasize the extreme importance of frequent $h$ and hygiene, respiratory etiquette, and environmental cleaning and disinfection, as well as the need of maintaining physical distances and avoidance of close, unprotected contact with people with fever or respiratory sym $\mathrm{ptom} \mathrm{s}$ (4).

In conclusion, the world is facing a completely new situation that deserves the comprehension of the population and close attention of the authorities. Following protocols to attend patients can prevent the dissemination of the virus, cross-infection, and the contamination of health care professionals. As the anti-coronaviral drugs and new vaccines are still under development, the fear of being infected will be present in the population for a long time and will play a role in economic and social programs. Moreover, new strategies need to be developed to enhance the existing teaching and learning protocols in Universities and to allow research to continue.

\section{Acknowledgements}

This work was supported by the Brazilian agencies São Paulo Research Foundation (FAPESP, grant no. 2015/23479-5, 2017/25242-8, 2019/19300-0), National Scientific and Technological Development Council (CNPq - 308162/2014-5, 303852/2019-4); Coordination for Improvement of Higher Education Personnel (CAPES - Finance Code 001) and University of Campinas research, teaching and extension support fund (FAEPEX - 2036/17).

The authors would like to thank all the researchers that, through their studies, have contributed to the understanding of this new and frightening disease COVID-19. The authors would like to thank David Henry Moon for English proofreading and technical support.

The authors deny any conflicts of interest related to this study.

\section{Resumo}

Este estudo descreve o surto de SARS-CoV-2 e o impacto na prática e Ensino em odontologia no Brasil. Foi realizada uma revisão da literatura acerca de interesses médico e odontológico baseada em achados recentes sobre a infecção (pesquisa e diretrizes relevantes). COVID-19 é uma doença sistêmica altamente transmissivel, imprevisivel, envolvendo a fase de replicação viral, seguida da fase inflamatória que pode evoluir para um estado de hiper inflamação, levando a uma "tempestade de citocinas" e outros sintomas tais como sepse, choque e falência múltipla de órgãos. Os dentistas são diretamente impactados pelo novo coronavírus uma vez que trabalham com a cavidade oral que é irrigada pela saliva, e recebe aerossóis e gotículas oriundas da respiração do paciente. Concluiu-se que o mundo está enfrentando uma situação completamente nova e merece a compreensão da população e atenção das autoridades. Seguir protocolos para o atendimento de paciente pode prevenir a disseminação do virus, infecção cruzada e a contaminação de profissionais da saúde. Novas estratégias precisam ser desenvolvidas para melhorar os protocolos de Ensino e aprendizagem existentes nas universidades e permitir que a pesquisa continue. 


\section{References}

1. Ahn DG, Shin HJ, Kim MH, Lee S, Kim HS, Myounge J, et al. Current status of epidemiology, diagnosis, therapeutics, and vaccines for novel Coronavirus Disease 2019 (COVID-19). J Microbiol Biotechnol 2020;30(3):313-324.

2. World Health Organization (WHO). https://www.who.int/emergencies/diseases/novelcoronavirus-2019/events-as-they-happen (accessed on 3/Jun/2020a).

3. Cascella M, Rajnik M, Cuomo A, Dulebohn SC, Di Napoli R. Features, evaluation and treatment coronavirus (COVID-19). In: StatPearls [Internet]. Treasure Island (FL): StatPearls Publishing; 2020 Jan.

4. World Health Organization (WHO). https://covid19. who.int/ (accessed on 27/Nov/2020b).

5. Sohrabi C, Alsafi Z, O'Neill N, Khan M, Kerwan A, Al-Jabir A et al. World health organization declares global emergency: A review of the 2019 novel coronavirus (COVID-19). Int J Surg 2020;76:716.

6. Babadaei MMN, Hasan A, Bloukh SH, Edis Z, Sharifi M, Kachooei $E_{1}$ et al. The expression level of angiotensin-converting enzyme 2 determines the severity of COVID-19: lung and heart tissue as targets. J Biomol Struct Dyn 2020;1:1-7.

7. Menachery VD, Yount BL Jr, Debbink K, Agnihothram S, Gralinski LE, Plante JA, et al. A SARS-like cluster of circulating bat coronaviruses shows potential for human emergence. Nat Med 2015;21(12):1508-1513.

8. Zhou P, Yang XL, Wang XG, Hu B, Zhang L, Zhang W, et al. A pneumonia outbreak associated with a new coronavirus of probable bat origin. Nature 2020;579(7798):270-273.

9. Dietz L, Horve PF, Coil DA, Fretz M, Eisen JA, Van Den Wymelenberg K. 2019 Novel coronavirus (COVID-19) pandemic: built environment considerations to reduce transmission. mSystems 2020;5(2):e00245-20.

10. Cui J, Li F, Shi ZL. Origin and evolution of pathogenic coronaviruses. Nat Rev Microbiol 2019;17(3):181-192.

11. Drosten $C$, Günther $S$, Preiser W, van der Werf $S$, Brodt HR, Becker $S$, et al. Identification of a novel coronavirus in patients with severe acute respiratory syndrome. N Engl J Med 2003;348(20):19671976.

12. Li R, Pei $S$, Chen $B$, Song $Y$, Zhang $T$, Yang $W$, et al. Substantial undocumented infection facilitates the rapid dissemination of novel Coronavirus (SARS-CoV-2). Science 2020a;368(6490):489-493.

13. Vignuzzi M, Stone JK, Arnold JJ, Cameron CE, Andino R. Quasispecies diversity determines pathogenesis through cooperative interactions in a viral population. Nature 2006;439(7074):344-348.

14. Chen J. Pathogenicity and transmissibility of 2019-nCoV - A quick overview and comparison with other emerging viruses. Microbes Infect 2020;22(2):69-71.

15. Stadnytskyi $V, B a x C E, B a x A$, Anfinrud P. The airborne lifetime of small speech droplets and their potential importance in SARS-CoV-2 transmission. Proc Natl Acad Sci U S A 2020;117(22):11875-11877.

16. Coutard B, Valle C, Lamballerie $X$, Canard B, Seidah NG, Decroly E. The spike glycoprotein of the new coronavirus 2019-nCoV contains a furin-like cleavage site absent in $\mathrm{CoV}$ of the same clade. Antiviral Res 2020;176:104742.

17. Hoffmann $M$, Kleine-Weber $H$, Schroeder $S$, Krüger N, Herrler T, Erichsen $S$, et al. SARS-CoV-2 cell entry depends on ACE2 and TMPRSS2 and is blocked by a clinically proven protease inhibitor. Cell 2020;181(2):271-80.e8.

18. Pinto D, Park YJ, Beltramello M, Walls AC, Tortorici MA, Bianchi S, et al. Cross-neutralization of SARS-CoV-2 by a human monoclonal SARS-CoV antibody. Nature 2020;583(7815):290-295.

19. Mason RJ. Pathogenesis of COVID-19 from a cell biology perspective. Eur Respir J 2020;55(4):2000607.

20. Sing $T$, Heston SM, Langel SN, Blasi M, Hurst JH, Fouda GG, et al. Lessons from COVID-19 in children: Key hypotheses to guide preventative and therapeutic strategies. Clin Infect Dis 2020;ciaa547.

21. Burrell CJ, Howard CR, Murphy FA. Chapter 7 - Pathogenesis of virus infections. Fenner and White's Medical Virology (Fifth Edition). 2017:77-104.

22. Wyman 0. Responding to Covid-19. Almanac. 2020 May 26. Update. https://www.oliverwyman.com/content/dam/oliver-wyman/v2/publications/cui20/March/COVID-19Primer.pdf (accessed on 03/Jun/2020).

23. Chandrashekar A, Liu J, Martinot AJ, McMahan $K$, Mercado NB, Peter $L$, et al. SARS-CoV-2 Infection protects against rechallenge in Rhesus macaques. Science 2020;369(6505):812-817.

24. Danis K, Epaulard O, Bénet T, Gaymard A, Campoy S, Botelho-Nevers E, et al. Cluster of Coronavirus Disease 2019 (Covid-19) in the French Alps, 2020. Clin Infect Dis 2020;71(15):825-832. 
25. World Health Organization (WHO) Modes of transmission of virus causing COVID-19: implications for IPC precaution recommendations [online]. Website https://www.who.int/news$\mathrm{room} /$ commentaries/detail/modes-of-transmissionof-virus-causing-covid-19-implications-for-ipcprecautionrecommendations. (accessed on 14/Apr/2020c).

26. Hindson J. COVID-19: faecal-oral transmission? Nat Rev Gastroenterol Hepatol 2020;17(5):259.

27. Xu Y, Li X, Zhu B, Liang H, Fang C, Gong Y, et al. Characteristics of pediatric SARS-CoV-2 infection and potential evidence for persistent fecal viral shedding. Nat Med 2020;26(4):502-5.

28. van Doremalen N, Bushmaker T, Morris DH, Holbrook MG, Gamble A, Williamson BN, et al. Aerosol and surface stability of SARS-CoV-2 as compared with SARSCoV-1. N Engl J Med 2020;382(16):1564-1567.

29. Cheng VCC, Wong SC, Chen JHK, Yip CCY, Chuang VWM, Tsang OTY, et al. Escalating infection control response to the rapidly evolving epidemiology of the Coronavirus Disease 2019 (COVID-19) due to SARS-CoV-2 in Hong Kong . Infect Control Hosp Epidemiol 2020;41(5):493-498.

30. Faridi S, Niazi S, Sadeghi K, Naddafi K, Yavarian J, Shamsipour M, et al. A field indoor air measurement of SARS-CoV-2 in the patient rooms of the largest hospital in Iran. Sci Total Environ 2020;725:138401.

31. Hamner L, Dubbel P, Capron I, Ross A, Jordan A, Lee J, et al. High SARS-CoV-2 attack rate following exposure at a choir practice - Skagit County, Washington, March 2020. MMWR Morb Mortal Wkly Rep 2020;69(19):606-610.

32. Centers for Disease Control and Prevention (CDC). https://www.cdc.gov/coronavirus/2019ncov/community/office-buildings.html. (accessed on 03/Jun/2020).

33. Guan WJ, Ni ZY, Hu Y, Liang WH, Ou CQ, He JX, et al. Clinical characteristics of Coronavirus Disease 2019 in China. N Engl J Med 2020;382(18):1708-1720.

34. Lauer SA, Grantz KH, Bi Q, Jones FK, Zheng Q, Meredith HR, et al. The incubation period of Coronavirus Disease 2019 (COVID-19) from publicly reported confirmed cases: estimation and application. Ann Intern Med 2020;172(9):577-582.

35. Huang C, Wang Y, Li X, Ren L, Zhao J, Hu Y, et al. Clinical features of patients infected with 2019 novel coronavirus in Wuhan, China. Lancet 2020;395(10223):497-506.

36. Lee $Y$, Min P, Lee $S$, Kim S-W. Prevalence and duration of acute loss of smell or taste in COVID19 Patients. J Korean Med Sci 2020;35(18):e174.

37. Ren LL, Wang YM, Wu ZO, Xiang ZC, Guo L, Xu T, et al. Identification of a novel coronavirus causing severe pneumonia in human: a descriptive study. Chin Med J (Engl) 2020;133(9):1015-24.

38. Wang W, Tang J, Wei F. Updated understanding of the outbreak of 2019 novel coronavirus (2019-nCoV) in Wuhan, China. J Med Virol 2020a;92(4):441-447.

39. Ottestad W, Søvik S. COVID-19 patients with respiratory failure: what can we learn from aviation medicine? Br J Anaesth 2020;S0007-0912(20):30226-30229.

40. Ruan Q, Yang K, Wang W, Jiang L, Song J. Clinical predictors of mortality due to COVID-19 based on an analysis of data of 150 patients from Wuhan, China. Intensive Care Med 2020;46(5):846-848.

41. Arentz M, Yim E, Klaff L, Lokhandwala S, Riedo FX, Chong M, et al. Characteristics and outcomes of 21 critically ill patients with COVID-19 in Washington State. JAMA 2020;323(16):1612-1614.

42. Tang N, Bai $H$, Chen $X$, Gong J, Li D, Sun Z. Anticoagulant treatment is associated with decreased mortality in severe Coronavirus Disease 2019 patients with coagulopathy. J Thromb Haemost 2020a;18(5):1094-1099.

43. Tang $N$, Li D, Wang $X$, Sun Z. Abnormal coagulation parameters are associated with poor prognosis in patients with novel coronavirus pneumonia. J Thromb Haemost 2020b;18(4):844-847.

44. Tang N, Pan Y, Xu C, Li D. Characteristics of emergency patients with markedly elevated D-dimer levels. Sci Rep. 2020c;10(1):7784.

45. American Thoracic Society. https://www.thoracic.org/patients/lung-disease-week/2011/ardsweek/general-info.php (accessed on 01/Jun/ 2020).

46. Wu Z, McGoogan JM. Characteristics of and important lessons from the Coronavirus Disease 2019 (COVID-19) outbreak in China: Summary of a report of 72314 cases from the Chinese Center for Disease Control and Prevention. JAMA. 2020.

47. European Centre for Disease Prevention and Control. Rapid risk assessment. Coronavirus Disease 2019 (COVID-19) pandemic: increased transmission in the EU/EEA and the UK. Seventh update. 2020 Mar 25, Stockholm, 2020.

48. World Health Organization (WHO). Laboratory testing for Coronavirus Disease 2019 (COVID-19) in suspected human cases: Interim guidance - 2 March 2020: https://www.who.int/publications- 
detail/laboratory-testing-for-2019-novel-coronavirus-in-suspected-human-cases-20200117 (accessed on 28/May/2020d).

49. Sapkota D, Thapa SB, Hasséus B, Jensen JL. Saliva testing for COVID-19? Br Dent J 2020;228(9):658-659.

50. Li M, Lei $P$, Zeng B, Li Z, Yu P, Fan B, et al. Coronavirus Disease (COVID-19): Spectrum of CT findings and temporal progression of the disease. Acad Radiol 2020b;27(5):603-608.

51. Fang $Y$, Zhang $H_{1}$ Xie J, Lin $M$, Ying L, Pang P. Sensitivity of chest CT for COVID-19: comparison to RT-PCR. Radiology 2020;296(2):E115-E117.

52. Caly L, Druce JD, Catton MG, Jans DA, Wagstaff KM. The FDA-approved drug ivermectin inhibits the replication of SARS-CoV-2 in vitro. Antiviral Res 2020;178:104787.

53. Wang $M$, Cao $R$, Zhang L, Yang $X$, Liu J, Xu M, et al. Remdesivir and chloroquine effectively inhibit the recently emerged novel coronavirus (2019-nCoV) in vitro. Cell Resm2020b;30(3):269-271.

54. Risch HA. Early outpatient treatment of symptomatic, high-risk covid-19 patients that should be ramped-up immediately as key to the pandemic crisis. Am J Epidemiol 2020;kwaa093.

55. Ye XT, Luo YL, Xia SC, Sun QF, Ding JG, Zhou Y, et al. Clinical efficacy of lopinavir/ritonavir in the treatment of Coronavirus Disease 2019. Eur Rev Med Pharmacol Sci 2020;24(6):3390-3396.

56. Beigel JH, Tomashek KM, Dodd LE. Remdesivir for the treatment of Covid-19 - Preliminary Report. N Engl J Med 2020;383.

57. Cao B, Wang Y, Wen D, Liu W, Wang J, Fan G, et al. A Trial of Lopinavir-Ritonavir in adults hospitalized with severe Covid-19. N Engl J Med 2020;382(19):1787-1799.

58. Zimmermann P, Ziesenitz VC, Curtis N, Ritz N. The immunomodulatory effects of macrolides-a systematic review of the underlying mechanisms. Front Immunol 2018;9:302.

59. World Health Organization (WHO).

https://www.who.int/csr/disease/coronavirus_infections/InterimGuidance_ClinicalManagement_NovelC oronavirus_11Feb13u.pdf (accessed on 09/May/2020e).

60. Horby TA, Lim P, Emberson WS, Mafham M, Bell JL, Linsell L, et al. Dexamethasone in hospitalized patients with Covid-19 - preliminary report. New Engl J Med 2020.

61. Bikdeli B, Madhavan MV, Jimenez D, Chuich T, Dreyfus T, Driggin E, et al. COVID-19 and thrombotic or thromboembolic disease: implications for prevention, antithrombotic therapy, and followup. J Am Coll Cardiol 2020;75(23):2950-2953.

62. World Health Organization (WHO). https://www.who.int/emergencies/diseases/novelcoronavirus-2019/covid-19-vaccines. (accessed on 24/March/2021).

63. Gavi. The Vaccine Alliance. https://www.gavi.org/covax-facility. (accessed on 24/March/2021).

64. Kohn WG, Harte JA, Malvitz DM, Collins AS, Cleveland JL, Eklund KJ. Guidelines for infection control in dental health care settings - 2003. J Am Dent Assoc 2004;135(1):33-47.

65. CFO. http://website.cfo.org.br/cfo-reforca-necessidade-do-ministerio-da-educacao-suspenderautorizacoes-para-abertura-de-novos-cursos-de-odontologia/ (accessed on 11/May/2020).

66. American Dental Association (ADA). ADA develops guidance on dental emergency, nonemergency care. https://www.ada.org/en/publications/ada-news/2020-archive/march/adadevelopsguidance-on-dental-emergency-nonemergency-care. (accessed on 18/May/2020).

67. CFO. https://website.cfo.org.br/consulta-do-cfo-revela-que-82-dos-cirurgioes-dentistasentrevistados-continuam-trabalhando-durante-a-pandemia/ (accessed on 24/March/2021).

68. Iyer P, Aziz K, Ojcius DM. Impact of COVID-19 on dental education in the United States. J Dent Educ 2020;84(6):718-722.

69. Ahmed MA, Jouhar R, Ahmed N, Adnan S, Aftab M, Zafar MS, et al. Fear and practice modifications among dentists to combat novel Coronavirus Disease (COVID-19) outbreak. Int J Environ Res Public Health 2020;17(8):2821.

70. O'Donnell VB, Thomas D, Stanton R, Maillard JY, Murphy RC, Jones SA, et al. Potential role of oral rinses targeting the viral lipid envelope in SARS-CoV-2 infection.

https://www.cardiff.ac.uk/_data/assets/pdf_file/0006/2393970/Potential-role-of-oral-rinsestargeting-the-viral-lipid-envelope-in-SARS-CoV-2-infection.pdf. (accessed on 3/Jun/2020).

71. Fini MB. What dentists need to know about COVID-19. Oral Oncol 2020;105:104741.

72. Barbosa-Ribeiro M, Arruda-Vasconcelos R, de-Jesus-Soares A, Zaia AA, Ferraz CCR, Almeida JFA, et al. Effectiveness of calcium hydroxide-based intracanal medication on infectious/inflammatory contents in teeth with post-treatment apical periodontitis. Clin Oral Investig 2019;23(6):2759-2766.

73. Louzada LM, Arruda-Vasconcelos R, Duque TM, Casarin RCV, Feres M, Gomes BPFA. Clinical investigation of microbial profile and levels of endotoxins and lipoteichoic acid at different phases of 
the endodontic treatment in teeth with vital pulp and associated periodontal disease. J Endod 2020;46(6):736-747.

74. Arruda-Vasconcelos R, Louzada LM, Feres M, Tomson PL, Cooper PR, BPFA Gomes. Investigation of microbial profile, levels of endotoxin and lipoteichoic acid in teeth with symptomatic irreversible pulpitis: a clinical study. Int Endod J 2021;54(1):46-60.

75. Consenso ABENO: Biossegurança no ensino odontológico. Pós-pandemia da COVID-19. http://www.abeno.org.br/arquivos/downloads/retomada_de_praticas_seguras_no_

ensino_odontologico.pdf. (Accessed 10March/2021).

76. Grazziotin-Soares R, Pires FS, Fontanella VRC. The development of a consensus document on biosafety practices. J Dent Educ. 2020 [Epub ahead of print].

Received: 04/12/2020

Accepted: 05/04/2021 